\title{
PENGARUH PEMBERIAN EFFLEURAGE MASSAGE AROMATHERAPHY LAVENDER TERHADAP KUALITAS TIDUR MALAM IBU HAMIL PRIMIGRVIDA TRIMESTER III DI KLINIK BIDAN MANDIRI DOMINGAS SURABAYA
}

\author{
Arkha Rosyaria Badrus ${ }^{1}$, Miftahul Khairoh ${ }^{2}$ \\ ${ }^{1,2}$ Fakultas Ilmu Kesehatan program Studi D-III Kebidanan \\ Universitas Dr.Soetomo Surabaya \\ Email:rosse.arkha@gmail.com,miftahkhairoh34@gmail.com
}

\begin{abstract}
A mid the high AKI and this AKB, it needs to be drawn red thread from the base of the problem, namely the welfare of pregnant women. From there, researchers have the idea to conduct scientific experiments using eufflurage massage with the aroma of lavender teraphy as a stimulation of the peripheral nerves and central nerves to produce and release the hormone endorphins. Predicted 78 percent of women have difficulty falling asleep during pregnancy. Physical and hormonal changes, causing discomfort to cause less sleep. One of the causes of sleep disorders of the third trimester pregnant women is back pain, frequent urination and anxiety before labor. Place of research conducted at Dominga's independent clinic followed by home visit given 7 days treat with frequency 15 minutes Massage. Research using pre experimental approach with pre and post test without control. The research designs undertaken in the study were measurement of Sleep Quality with The Pittsburgh Sleep Quality Index (PSQI). The resulting data is not normally distributed, the statistical test using Mc Nemar test obtained p: $0.004<0.05$ and the value of $Z$ arithmetic $0.774<1.96$ then Ho rejected and Ha received due to endhorpin hormone that can provide relaxation in pregnant women third trimester
\end{abstract}

Keywords :Massage Effleurage, Night Sleep Quality Pregnant Trimester III 


\section{PENDAHULUAN}

Ibu hamil merupakan manusia yang memilki kebutuhan dasar sehari-hari berupa nutrisi, tidur, hygiene, kenyamanan, oksigenasi, dan eliminasi. Kebutuhan dasar ibu hamil yang paling mudah adalah terpenuhinya kebutuhan akan tidur dan istirahat. Tidur adalah hal yang paling esensial bagi kesehatan. Tidur yang berkualitas akan menghasilkan kesegaran dan kebugaran di saat terbangun. Tidur yang tidak adekuat dan berkualitas buruk dapat menyebabkan gangguan psikologis dan Fisiologis pada ibu hamil (Riksana,2013:22)

Data hasil polling tidur di Amerika oleh National Sleep Foundation tahun 2016 didapat $97,3 \%$ wanita hamil trimester tiga selalu terbangun dimalam hari. Rata-rata 311 kali setiap malam( National sleep Foundation, 2016) danMenurut penelitian yang dilakukan University of Medicine and

Dentistry of New jersey, New Brunswick, gangguan tidur ini meningkatkan risiko meningginya tekanan darah saat hamil menjadi empat kali lipat. Parahnya lagi risiko mengalami diabetes saat hamil juga dapat meningkat dua kali lipat emosi meliputi kecemasaan, rasa takut dan depresi (Andari et al,2013).

Penelitian yang dilakukan University of California di San Francisco menemukan fakta, wanita yang tidur kurang dari 6 jam per malam memiliki kemungkinan menjalani operasi caesar 4,5 kali lebih besar. Menurut survey dari 1,1 juta penduduk di Amerika yang dilakukan oleh American Cancer Society menemukan bahwa mereka yang dilaporkan tidur sekitar 7 jam setiap malam memiliki tingkat kematian terendah, sedangkan orang yang tidur kurang dari 6 jam atau 8 jam lebih tinggi tingkat kematiannya. Tidur selama 8,5 jam atau lebih setiap malam dapat meningkatkan angka kematian sebesar 155 (Andari et al,2013).

Hasil penelitian Irmayana tahun 2013 tentang pola tidur ibu hamil trimester tiga di RSU Dr. Pirngadi Medan menunjukkan bahwa ibu hamil mengalami gangguan pola tidur karena frekuensi terbangun $(50 \%)$ dan mengalami ketidakpuasan saat tidur (31\%). Gangguan tidur tidak hanya dialami oleh wanita hamil fisiologis namun juga oleh wanita hamil dengan diabetes gestasional, preeklamsiaeklamsia, hyperemesis Gravidarum, Hipertensi. Berdasarkan data dari Universitas Indraprasta tahun 2012, 34\% kaum wanita mengalami insomnia.

Berbagai macam cara dilakukan untuk mengatasi masalah kualitas tidur pada seseorang, baik dengan terapi farmakologi maupun terapi non farmakologi. Terapi farmakologi misalnya dengan bantuan obat tidur atau obat penenang. Pendekatan secara non farmakologi dapat menggunakan massage dan aromatherapy yang memberikan efek yang baik bagi tubuh ibu hamil karena massage merangsang tubuh melepas senyawa endhorpin yang dapat menjadi pereda sakit alami dan mermberikan rileksasi. Massage effleurage adalah salah satu prosedur massage yang ada pada ibu hamil dapat dilakukan dengan cara melakukan usapan lembut pada daerah vertebrae lumbal, thoracic vertebrae hingga os scavula kembali lagi ke bawah melalui thoracic vertebrae dengan tekanan ringan sedang - ringan yang nantinya dapat merangsang pengeluaran senyawa endhorpin pada ibu secara alami pada torakal ke 12 dan 10 (Wulandari dkk, 2015).

\section{PERUMUSANMASALAH}

Berdasarkanrumusanlatarbelakangmasal ahdiatasmakadirumuskanmasalahpeneliti anadalah "Pengaruh Pemberian Effleurage Massage Aromatherapy Lavenderterhadap kualitas tidur malam ibu hamil primigravida Trimester III di Klinik Bidan Mandiri Domingas Surabaya"

\section{TUJUANPENELITIAN}

1. TujuanUmum

Untuk mengetahui Pengaruh Pemberian Effleurage Massage Aromatherapy Lavender terhadap kualitas tidur malam ibu hamil primigravida Trimester III di Klinik Bidan Mandiri Domingas Surabaya

2. TujuanKhusus

a. Mengidentifikasi kualitas tidur malam ibu hamil Primigravida trimester III sebelum di berikan Effleurage Massage Aromatherapy Lavender 
b. Mengidentifikasikualitas tidur malam ibu hamil Primigravida trimester III sesudah diberikan Effleurage Massage Aromatherapy Lavender

c. MenganalisisPengaruh Pemberian Effleurage Massage Aromatherapy Lavender terhadap kualitas tidur malam ibu hamil primigravida Trimester III di Klinik Bidan Mandiri Domingas Surabaya

\section{MANFAATPENELITIAN}

1. Manfaat Teoritis

Diharapkan dapat menambah khasanah pengetahuan dan menambah informasi khususnya bagi ilmu kebidanan terkait intervensi komplementer yang dapat membantu ibu hamil trimester III mengurangi gangguan kualitas tidur melalui Effleurage Massage Aromatherapy Lavender menjadi salah satu bacaan yang bermanfaat untuk penelitian dimasa yang akan datang.

2. Manfaat Praktis

Diharapkan peneliti ini dapat menjadi informasi bagi lembaga terkait untuk mensukseskan program pemerintah dalam penuruanan angka kematian Ibu (AKI) dan Angka Kematian bayi (AKB) melalui asuhan "sayang ibu"secara komprehensif yang pelaksanaanya dapat berupa pemberian Effleurage Massage Aromatherapy Lavender pada ibu hami Trimester III

\section{DESAIN PENELITIAN}

Jenis penelitian ini yaitu kuantitatif, eksperimen menggunakan rancangan penelitian Quansi Experimental dengan Pre and Post without control ( kontrol diri sendiri ) yang artinya peneliti hanya melakukan intervensi pada satu kelompok tanpa pembanding. (Heriyanto, 2016:27)

\section{POPULASI DAN SAMPEL}

Populasi dalam penelitian ini adalah seluruh ibu hamil Trimester III di BPM Domingas Surabaya.

Sampel Jumlah sampel dihitung dengan menggunakan tehnik total samplingsehingga diperolah jumlah sampel 15 orang ibu hamil trimester III.

\section{$\begin{array}{lll}\text { TEMPAT DAN WAKTU } & \end{array}$ PENELITIAN}

Tempat penelitian dilakukan di Bidan Praktek Mandiri Domingas Surabaya dan waktu penelitian dilaksanakan pada bulan 15 Januari-10 Februari 2018

\section{HASIL PENELITIAN}

Penelitian telah dilakukan terhadap 15 orang responden yang memenuhi kriteria inklusi dan eksklusi.

\begin{tabular}{ccc}
$\begin{array}{l}\text { Kualitas } \\
\text { Massage Effleurage. }\end{array}$ & $\begin{array}{c}\text { tidur } \\
\text { sebelum }\end{array}$ \\
\hline $\begin{array}{c}\text { Kualitas } \\
\text { tidur }\end{array}$ & Frekuensi & Presentase(\%) \\
\hline Baik & 0 & 0 \\
Buruk & 15 & 100 \\
\hline Total & 15 & 100 \\
\hline
\end{tabular}

Tabel 5.1 Distribusi frekuensi kualitas tidur ibu hamil trimester III sebelum diberikan massage effleurage dengan PSQI di BPM Ny. Domingas, Surabaya 2018.

Tabel 1dapat diketahui bahwa kualitas tidur responden ibu hamil trimester III sebelum diberikan massage effleurage yang mengalami kualitas tidur buruk adalah 15 orang bu hamil trimester III (100\%)

Kualitas tidur sesudah diberikan Massage Effleurage

\begin{tabular}{ccc}
\hline $\begin{array}{c}\text { Kualitas } \\
\text { tidur }\end{array}$ & Frekuensi & Presentase \\
\hline Baik & 9 & 60 \\
Buruk & 6 & 40 \\
\hline Total & 15 & 100 \\
\hline
\end{tabular}

Tabel 5.2 Distribusi frekuensi kualitas tidur ibu hamil trimester III sesudah diberikan massage effleurage dengan PSQI di BPM Ny. Domingas, Surabaya 2018. 
Dapat diketahui bahwa kualitas tidur responden ibu hamil trimester III sesudah diberikan massage effleurage sebanyak 9 orang ibu hamil trimester III(60\%) mengalami kualitas tidur baik dan sebanyak 6 orang ibu hamil trimester III( $40 \%)$ masih mengalami kualitas tidur buruk.

Tabulasi silang kualitas tidur ibu hamil trimester III sebelum dan sesudah diberikan Massage Effleurage

\begin{tabular}{ccccccc}
\hline $\begin{array}{c}\text { Kualitas } \\
\text { tidur }\end{array}$ & \multicolumn{2}{c}{$\begin{array}{c}\text { Sebelum } \\
\text { massage }\end{array}$} & & \multicolumn{2}{c}{$\begin{array}{c}\text { Sesudah } \\
\text { massage }\end{array}$} \\
\hline & f & $\%$ & Mean & f & \% & Mean \\
\hline Baik & 0 & 0 & 9,33 & 9 & 60 & 5,53 \\
Buruk & 15 & 100 & & 6 & 40 & \\
\hline Total & 15 & 100 & & 15 & 100
\end{tabular}

Berdasarkan tabel 5.3 distribusi silang frekuensi tidur ibu hamil trimester III sebelum dan sesudah diberikan Massage Effleurage mengalami kenaikan pada kualitas tidur baik sebanyak 9 orang ibu hamil trimester III (60\%) dan mengalami penurunan pada kualitas tidur buruk menjadi 6 ibu hamil trimester III (40\%) dengan Mean 5,53.

Efektifitas Massage Effleurage terhadap kualitas tidur malam ibu hamil trimester III

\begin{tabular}{ccc}
\hline Uji Data & $\begin{array}{c}\mathbf{Z} \\
\text { hitung }\end{array}$ & Sign \\
\hline $\begin{array}{c}\text { Massage effleurage } \\
\text { sebelum dan sesudah }\end{array}$ & 0,774 & 0,004 \\
\hline
\end{tabular}

Tabel $5.4 \quad$ Uji efektifitas massage effleurage terhadap kualitas tidur malam ibu hamil trimester III dengan menggunakan uji Mc Nemar dengan nilai signifikasi $p<0,05$. Dengan hasil sebagai berikut

Berdasarkan hasil uji efektifitas Mc Nemar test di peroleh nilai Z-hitug sebesar $0,774<1,96$ (derajat kepercayaan $5 \%=0,475$, pada tabel $\mathrm{Z}$ nilai 0,475 yaitu 1,96 ) dengan nilai signifikan (p) sebesar $0,004<0,05$. Maka berdasarkan Hipotesis penelitian dapat disimpulkan bahwa jika pvalue $<0,05$ maka Ho di tolak \& Ha diterima yang berarti ada efektifitas massage effleurage terhadap kualitas tidur malam ibu hamil trimester III.

Hal ini sesuai dengan teori bahwa Massage effleurage adalah salah satu prosedur massage yang ada pada ibu hamil dapat dilakukan dengan cara melakukan usapan lembut pada daerah vertebrae lumbal, thoracic vertebrae hingga os scavula kembali lagi ke bawah melalui thoracic vertebrae dengan tekanan ringan sedang - ringan yang nantinya dapat merangsang pengeluaran senyawa endhorpin pada ibu secara alami pada torakal ke 12 dan 10 (Wulandari dkk,2015). Dan merurut ahli massage ibu hamil trimester III memperbolehkan dilakukannya massage effleurage sesering mungkin karena memiliki manfaat yang baik untuk ibu hamil sebagai relaksasi dan teknik massage tidak dilakukan dengan menyentuh daerah kontraindikasi/menimbulkan kontrasi (Sutarmi dkk,2014:27)

Berdasarkan mekanisme kerja sistem syaraf bahwa Massage Effleurage adalah massage yang di berikan secara lembut pada permukaan kulit yang dapat berfungsi sebagai pereda nyeri, bekerja dengan cara mengaktifkan transmisi serabut saraf sensori A-beta yang lebih cepat sebagai neurotransmiter, sehingga menurunkan transmisi nyeri yang di hantarkan melalui serabut $\mathrm{C}$ dan A-delta berdiameter kecil sekaligus menutup gerbang sinap untuk transmisi impuls nyeri (Sumitriyani,2015:46). Dan berdasarkan sistem hormonal yaitu Endorphin merupakan sistem penekanan nyeri yang dapat diaktifkan dengan merangsang daerah reseptor endhorphin di zat kelabu periaqueduktus otak tengah. Pemberian massage effleurage pada daerah torakal 10 sampai 12 dan lumbal 1 yang merupakan sumber persarafan pada uterus dan cervik dapat merangsang reseptor syaraf asenden, dimana rangsangan tersebut akan dikirim ke hipotalamus dengan perjalanan melalui spinal cord, diteruskan ke bagian pons dilanjutkan ke bagian kelabu pada otak tengah (periaqueduktus), rangsangan yang diterima oleh periaqueduktus ini disampaikan kepada hipotalamus, dari hipotalamus inilah melalui alur saraf desenden hormon endorphin dikeluarkan ke pembuluh darah (Sumitriyani, 2015:47) 


\section{KESIMPULAN DAN SARAN}

\section{KESIMPULAN}

Kesimpulan yang dapat diambil dari penelitian ini adalah terdapat Pengaruh Pemberian Effleurage Massage Aromatherapy Lavender terhadap kualitas tidur malam ibu hamil primigravida Trimester III di Klinik Bidan Mandiri Domingas Surabaya

2. SARAN

a. Diharapkan melalui penelitian ini massage effleurage pada ibu hamil trimester III lebih banyak diterapkan sehingga mampu menurunkan morbiditas bahkan mortalitas ibu hamil.

b. Perlu dilakukan sosialisasi lebih luas lagi tentang massage effleurage agar responden dan masyarakat yakin terhadap manfaat massage effleurage.

\section{DAFTAR PUSTAKA}

Danuatmaja, Bonny.(2004). Persalinan Normal Tanpa Rasa Sakit. Jakarta: Puspa Swarna.

Departemen Kesehatan. (2006). Profil Kesehatan Sumatra Utara. Medan: Dinkes . (2004). Asuhan Persalinan Normal. Jakarta: Depkes.

Henderson, C. (2006). Buku Ajar Konsep Kebidanan. Jakarta: EGC.

Herdiana,Trirejeki.Dr. (2009). Tips Pijat Perineum. Liu, David.T.Y. (2008). Manual Persalinan Edisi 3. Jakarta: EGC.

Iis Sinsin. (2008). Seri Kesehatan Ibu dan Anak Masa Kehamilan dan Persalinan.Jakarta: Alex Media.

Indiarti. (2009). Panduan Lengkap Kehamilan, Persalinan,dan
Perawatan Bayi. Yogyakarta: Diglossia Media.

Kartika.(2008). Sehat Setelah Melahirkan. Yogyakarta: Kawan Kita Kelaten.

Liwellyin, William. (2002). Obstetri dan Genekologi. Jakarta: WidyaMedika.

Liu, David.T.Y. (2008). Manual Persalinan Edisi 3. Jakarta: EGC.

Mochtar, Rustam. Prof.Dr.MPH. (1998).Sinopsis Obstetri jilid 1. Jakarta: EGC.

(1998). Sinopsis Obstetri 2. Jakarta: EGC.

Mongan, Marie F.M.Ed.M.Hy. (2007). Hypno Birthing: Metode Melahirkan Secara Aman, Mudah, dan Nyaman. Jakarta: BIP.

Nolan, Mary. ( 2004). Kehamilan dan Melahirkan. Jakarta: ARCAN.

Notoatmodjo, S. (2005).Metodologi Penelitian Kesehatan. Jakarta: RinekaCipta.

Sastroasmoro, Sudigdo. (2008). DasarDasar Metodologi Penelitian klinis. Jakarta:SagungSeto.

Schott, J dan Priest, J. (2002).Kelas Antenatal. Jakarta: EGC.

Simkin, P danAncheta, R. (2005).Buku Saku Persalinan. Jakarta: EGC.

Stoppard, Miriam. Dr. (2007). Panduan Mempersiapkan Kehamilan dan Kelahiran.Yogyakarta: PustakaBelajar.

Wiknjosastro, Hanifa. Prof.dr.DSOG. (2005).Ilmu Kebidanan. Jakarta: YayasanBinaPustakaSarwonoPraw irohardjo.

Whalley, Janet.RN, BSN.(2002). Panduan Praktis bagi Calon Ibu Kehamilan dan Persalinan. Jakarta: BIP. 